\title{
Histopathology and host response in lithodid crabs parasitized by Briarosaccus callosus
}

\author{
Albert K. Sparks \& J. Frank Morado
}

\begin{abstract}
Resource Assessment and Conservation Engineering Division, Northwest and Alaska Fisheries Center, National Marine Fisheries Service, National Oceanic and Atmospheric Administration, 7600 Sand Point Way NE., Seattle, Washington 98115 , USA
\end{abstract}

\begin{abstract}
Two red (Paralithodes camtschatica) and 26 golden (Lithodes aequispina) king crabs parasitized by the rhizocephalan Briarosaccus callosus were examined microscopically for histopathological effects of and host response to the parasite. Although numerous organs were invaded and tissues displaced, replaced or compacted, there was little necrosis or degeneration of tissues other than gonads. Host response to healthy $B$. callosus was negligible, but degenerating rootlets of the parasite elicited heavy hemocytic response in a typical crustacean foreign-body reaction.
\end{abstract}

\section{INTRODUCTION}

Boschma (1962) described Briarosaccus callosus and suggested it may be a cosmopolitan parasite of lithodid crabs, reporting it from Lithodes aequispina in the Bering Sea, L. agassizii off southeastern United States, and L. antarcticus and Paralomis granulosa in the Antarctic and sub-Antarctic regions. Subsequently, Boschma \& Haynes (1969) reported it from Paralithodes camtschatica in southeastern Alaska. Hawkes et al (1985a) first reported $B$. callosus from Paralithodes platypus, again from southeast Alaska.

Prevalences of infection have been investigated in blue king crab Paralithodes platypus (Hawkes et al. $1985 a, b)$, red king crab $P$. camtschatica (Hawkes et al. 1986), and golden king crab Lithodes aequispina, as have gross observations on the effect on growth, reproduction and migratory behavior of parasitized crabs (Sloan 1984, 1985, Bower \& Sloan 1985, Hawkes et al. 1986), but heretofore the histopathological effects have been only briefly mentioned (Sparks 1985, Sparks \& Morado 1985).

\section{MATERIALS AND METHODS}

Two red king crabs Paralithodes camtschatica with Briarosaccus callosus externa were shipped alive to our laboratory where necropsies were performed and random samples of the major organ systems were excised, fixed, and processed by standard histotechniques. All other crabs were collected during crab population surveys by the Resource Assessment and Conservation Engineering Division (RACE) of the National Marine Fisheries Service (NMFS) or Alaska Department of Fish and Game (ADF \& G). Necropsies were performed aboard ship by personnel of our laboratory, the NMFS Kodiak Laboratory or the ADF\&G. The fixed tissues were processed in our laboratory where microscopical observations were made on the histopathological effects of $B$. callosus and host response to the parasite in parasitized crabs.

\section{RESULTS}

Despite relatively large samples from a large area of the western Gulf of Alaska and Bering Sea over a 3 yr period (Fig. 1; Table 1), no blue king crabs ( $\mathrm{n}=224$ ) and only 2 red king crabs were infected by Briarosaccus callosus. As previously noted, the 2 infected red king crabs of 764 were sent to us because they possessed $B$. callosus externa. Twenty-nine additional red king crabs collected and necropsied from Cook Inlet the same year (1982) were uninfected.

Twenty-four of 143 golden king crabs were parasitized by Briarosaccus callosus, with infected individuals in every collection from all areas sampled (Table 1). We have little confidence in the randomness ot these prevalence data because crabs with externae 
were possibly selected for necropsy. However, in the 1984 collection ( $n=94$ ), only one parasitized crab had an externa, another had a recognizable scar from a lost externa, and the remaining 8 had no reported external features of $B$. callosus parasitism.

At the light microscopy level, there were no discernible differences between the 2 species in the tissues invaded and host response to interna of normal appearance. Branches of the interna appear to have a predilection for connective tissue (Fig. 2), but rootlets of the interna penetrated the connective tissue capsule of several organs, particularly the thoracic ganglion (Fig. 3), brain and major nerves (Fig. 4) and ovary. Penetration into these organs resulted in displacement and also compaction of normal tissue. The wall of the

Table 1. Paralithodes camtschatica, P. platypus, and Lithodes aequispina. Prevalence of infection by Briarosaccus callosus of red, blue and golden king crabs from the Gulf of Alaska and Bering Sea

\begin{tabular}{|c|c|c|c|c|}
\hline Year & Location & $\begin{array}{c}\text { Sample } \\
\text { size }\end{array}$ & Infected & $\begin{array}{c}\text { Preva- } \\
\text { lence } \\
(\%)\end{array}$ \\
\hline \multicolumn{5}{|c|}{ p. camtschatica } \\
\hline 1982 & Kodiak & 5 & 0 & 0 \\
\hline 1982 & $\mathrm{BB}$ & 40 & 0 & 0 \\
\hline 1982 & $\mathrm{CI}$ & 7 & 2 & $26.6^{\circ}$ \\
\hline 1982 & Auke Bay & 1 & 0 & 0 \\
\hline 1983 & Kodiak & 6 & 0 & 0 \\
\hline 1983 & $\mathrm{BB}$ & 54 & 0 & 0 \\
\hline 1983 & $\mathrm{CI}$ & 29 & 0 & 0 \\
\hline 1984 & Kodiak & 8 & 0 & 0 \\
\hline 1984 & $\mathrm{BB}$ & 81 & 0 & 0 \\
\hline 1984 & Auke Bay & 8 & 0 & 0 \\
\hline 1985 & Kodiak & 314 & 0 & 0 \\
\hline 1985 & $\mathrm{BB}$ & 105 & 0 & 0 \\
\hline 1985 & NS & 106 & 0 & 0 \\
\hline \multicolumn{5}{|c|}{ P. platypus } \\
\hline 1983 & PI & 60 & 0 & 0 \\
\hline 1983 & St. Mat. & 8 & 0 & 0 \\
\hline 1984 & $\mathrm{PI}$ & 26 & 0 & 0 \\
\hline 1984 & St. Mat. & 42 & 0 & 0 \\
\hline 1984 & Kodiak & 3 & 0 & 0 \\
\hline 1985 & $\mathrm{PI}$ & 27 & 0 & 0 \\
\hline 1985 & St. Mat. & 51 & 0 & 0 \\
\hline 1985 & NS & 7 & 0 & 0 \\
\hline \multicolumn{5}{|c|}{ L. aesquispina } \\
\hline 1983 & WA & 9 & 4 & 44.4 \\
\hline 1983 & $\mathrm{PC}$ & 12 & 2 & 16.7 \\
\hline 1983 & $\mathrm{ZC}$ & 28 & 8 & 28.6 \\
\hline 1984 & WA & 94 & 10 & 10.6 \\
\hline Total & & 1131 & 26 & 2.2 \\
\hline \multicolumn{5}{|c|}{$\begin{array}{l}\text { Not random (see text) } \\
\text { BB: Bristol Bay; CI: Cook Inlet; NS: Norton Sound; PI: } \\
\text { Pribilof Islands; St. Mat.: St. Matthew Island; WA: West- } \\
\text { ern Aleutians; PC: Pribilof Canyon; ZC: Zhemchug Can- } \\
\text { yon }\end{array}$} \\
\hline
\end{tabular}

gastrointestinal tract was always invaded, where normal tissue components were again displaced (Fig. 5). Degeneration or necrosis of tissues other than gonad was rare even in heavily parasitized hosts. The marked degeneration (Fig. 6) of mature and developing ova in infected females appeared to be independent of actual penetration of ovary by rootlets of Briarosaccus callosus.

The effect, or perhaps the progression, on the testes of male crabs is less clear. Neither of the red king crabs, both males, had gonads recognizable at necropsy. Four of the 13 male golden king crabs had grossly recognizable, but atrophied, testes; the remaining 9 did not, but all possessed spermatophores with sperm of normal appearance. Testes, when present, ranged from near normai size, appearance, and mitotic activity (Fig. 7) to markedly atrophied, with thickened capsules, mitotic arrest, degenerating spermatocytes and conspicuous decline in sperm production (Fig. 8).

Briarosaccus callosus with normal-appearing externa elicited little or no host response and, except for the degeneration of ova and testes, little obvious histopathological damage other than compression or replacement of tissue by the proliferating rootlets of the parasite (Fig. 2 to 6). However, when the rootlets of the interna were obviously degenerating, there was an intense mixed hemocytic infiltration followed by granuloma formation and hemocytic encapsulation of the degenerating rhizocephalan rootlets (Fig. $9 \& 10$ ). Apparently, these lesions eventually become melanized and the degenerated rootlets difficult or impossible to recognize.

\section{DISCUSSION}

We have not attempted to determine the progression of the internal infection by the proliferating rootlets of Briarosaccus callosus, but it is apparently consistent with that of Sacculina carcini in experimental infections of Carcinus maenas described by Payen et al. (1981) and Rubiliani et al. (1980). Invasion of the thoracic ganglion and other parts of the nervous system occurs frequently and presumably has a profound effect on neuroendocrine controls (Rubiliani et al. 1980, Rubiliani-Durozoi et al. 1980, Rubiliani \& Godette 1981). Arrestment of gametogenesis and degeneration of developing ovary and testes has been shown to occur with or without invasion of the gonads by rootlets of the parasite (Rubiliani et al. 1980).

We believe that host response occurs only when rootlets of the interna begin to degenerate, probably subsequent to injury to or loss of the externa. The degenerating rootlets are then recognized as 'non-self', eliciting the characteristic crustacean foreign-body 
response of hemocytic infiltration, encapsulation and melanization. Most infected crabs having a marked host response were noted to have scars from lost externa. We believe that those with host response, but not so noted, had scars that were not recognized at necropsy.

We cannot explain the absence of Briarosaccus callosus in our samples of blue king crabs from St.

Fig. 1. Schematic showing collection sites of Alaskan king crabs
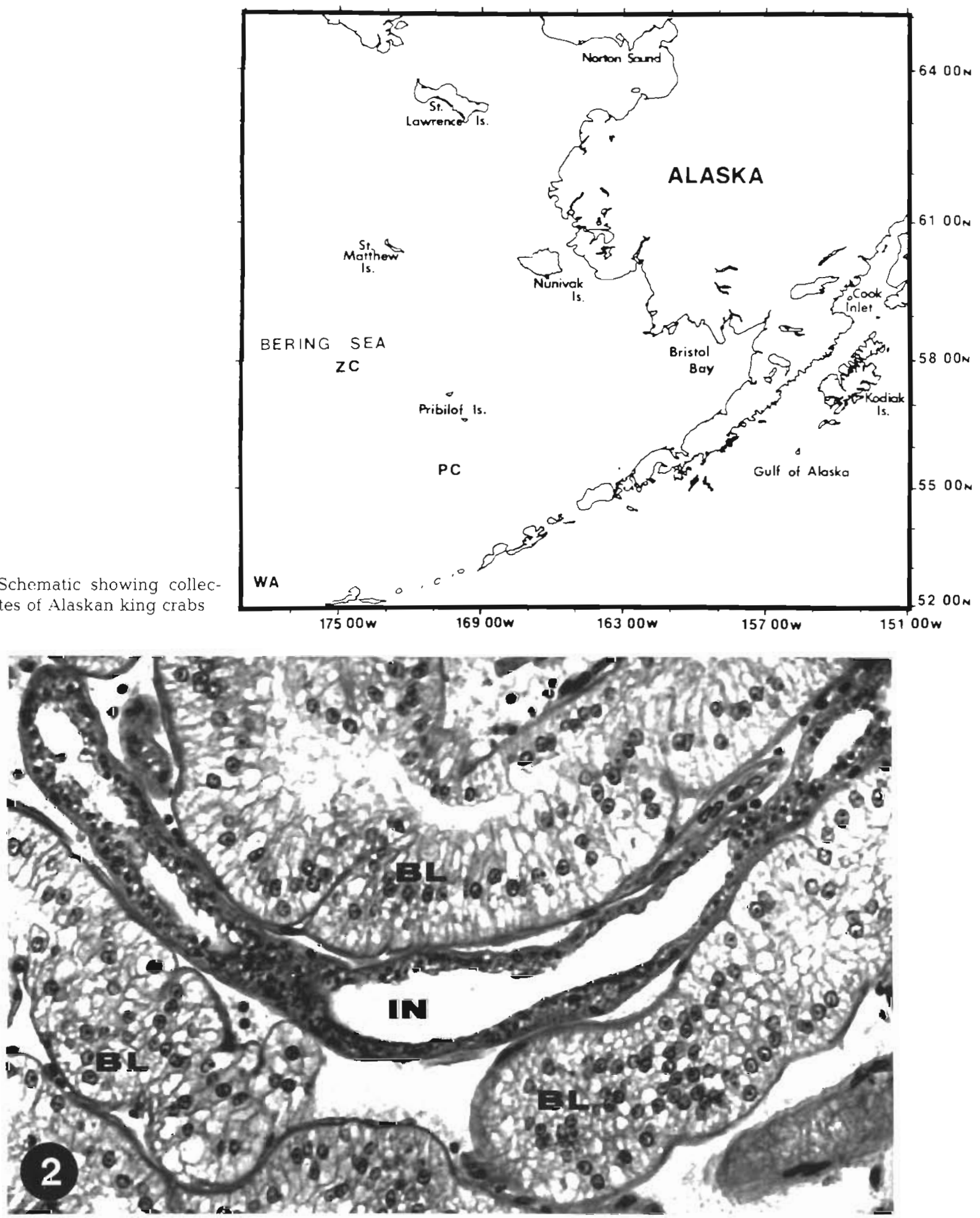

Fig. 2. Paralithodes camtschatica. Interna (IN) of Briarosaccus callosus in bladder (BL) connective tissue. Hematoxylin and eosin $250 \times$ 


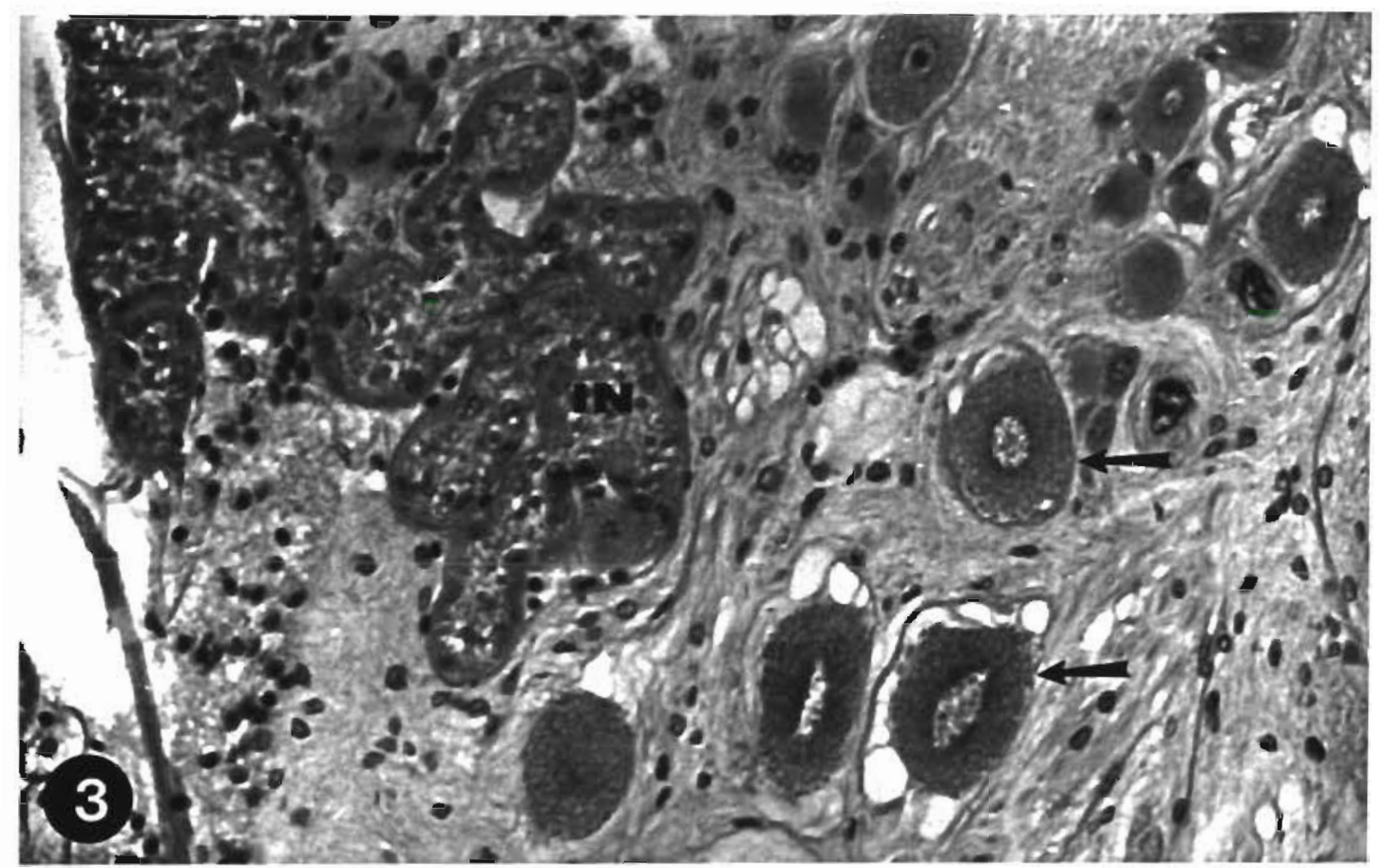

Fig. 3. Paralithodes camtschatica. Invasion by Briarosaccus callosus (IN) of the thoracic ganglion. Arrows: neurosecretory cells. Hematoxylin and eosin $250 \times$

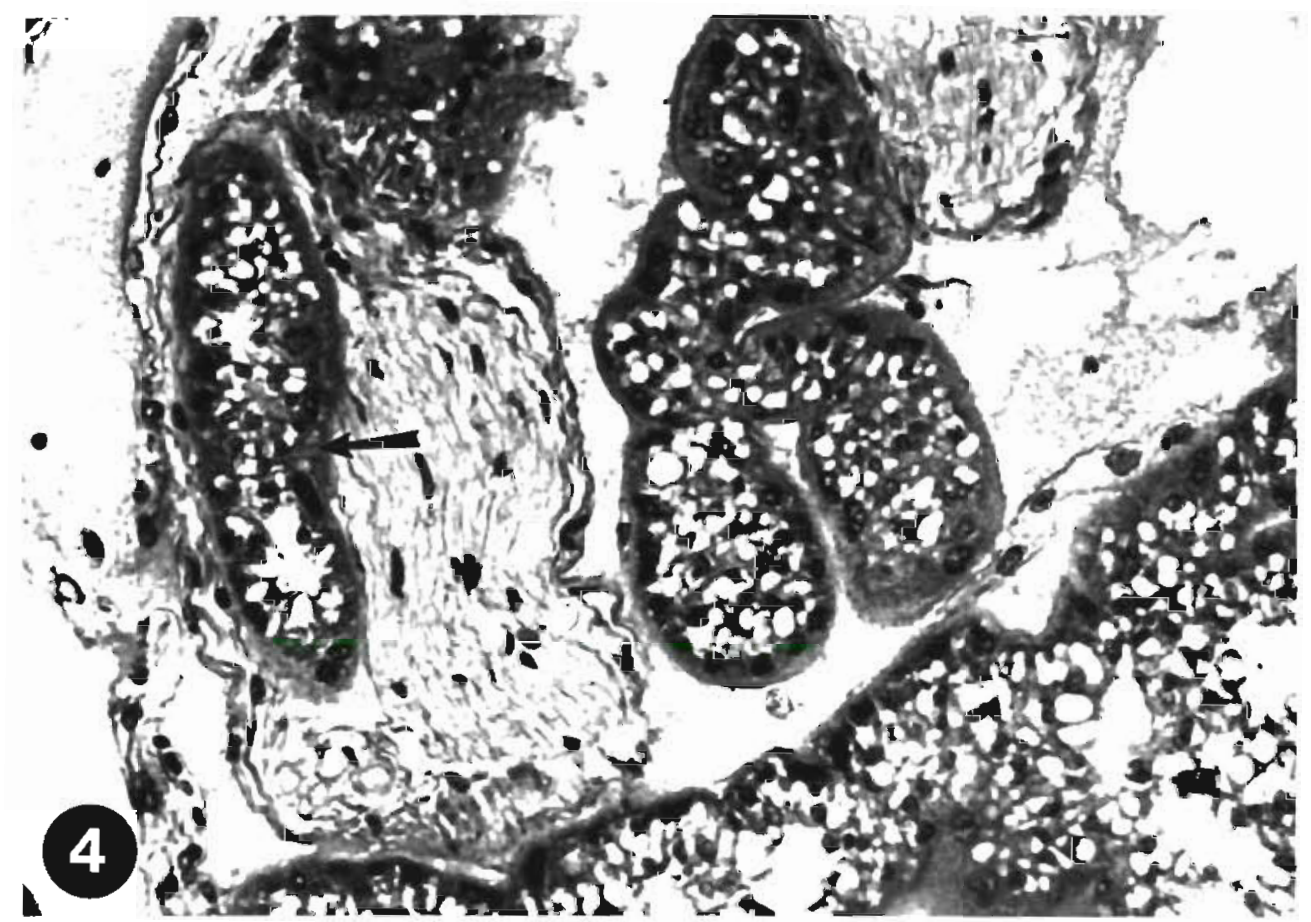

Fig. 4. Paralithodes camtschatica. Invasion by Briarosaccus callosus of major nerves (arrow). Hematoxylin and eosin $220 \times$ 


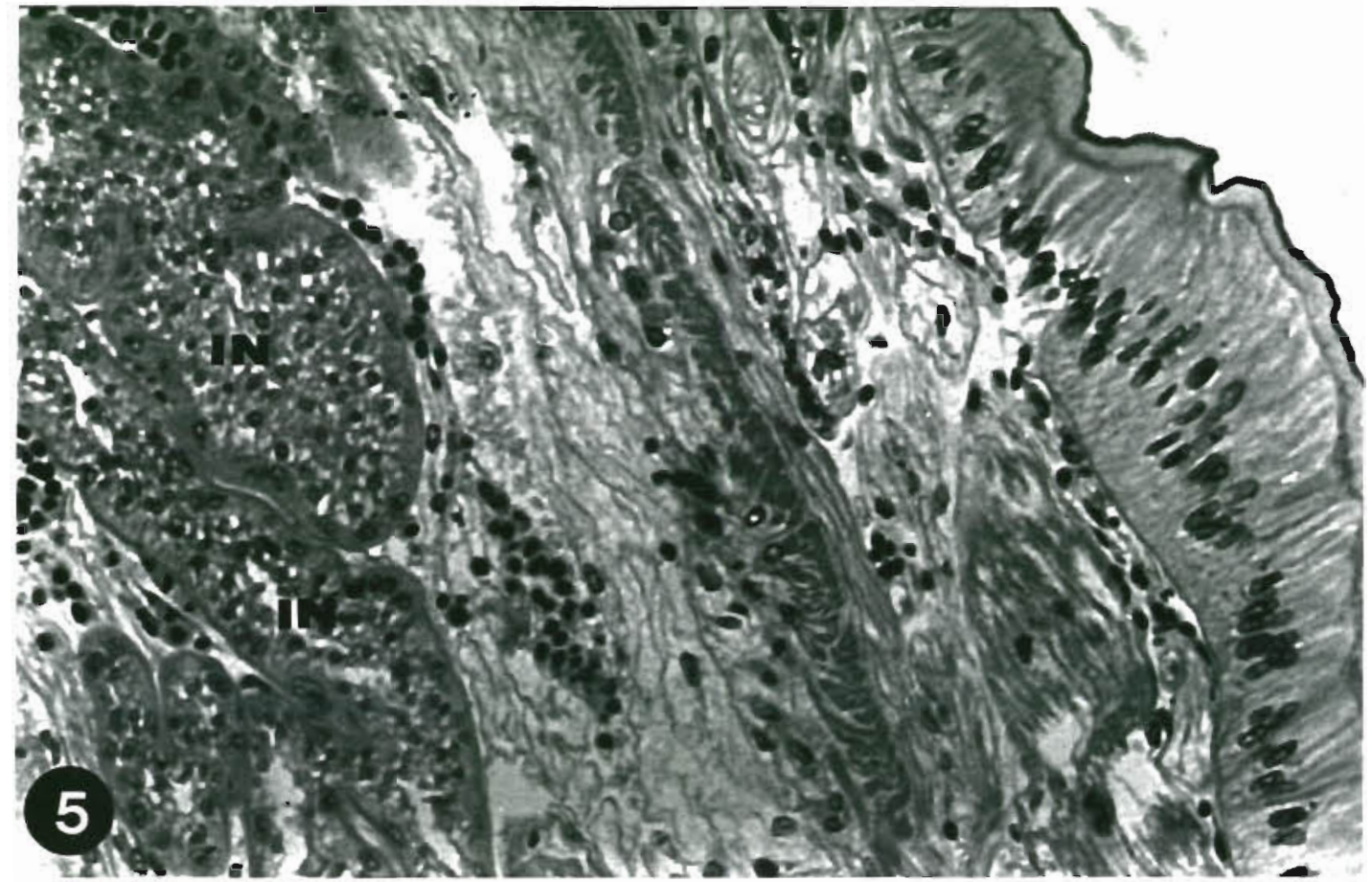

Fig. 5. Paralithodes camtschatica. Invasion by Briarosaccus callosus (IN) of hindgut wall. Hematoxylin and eosin $250 \times$

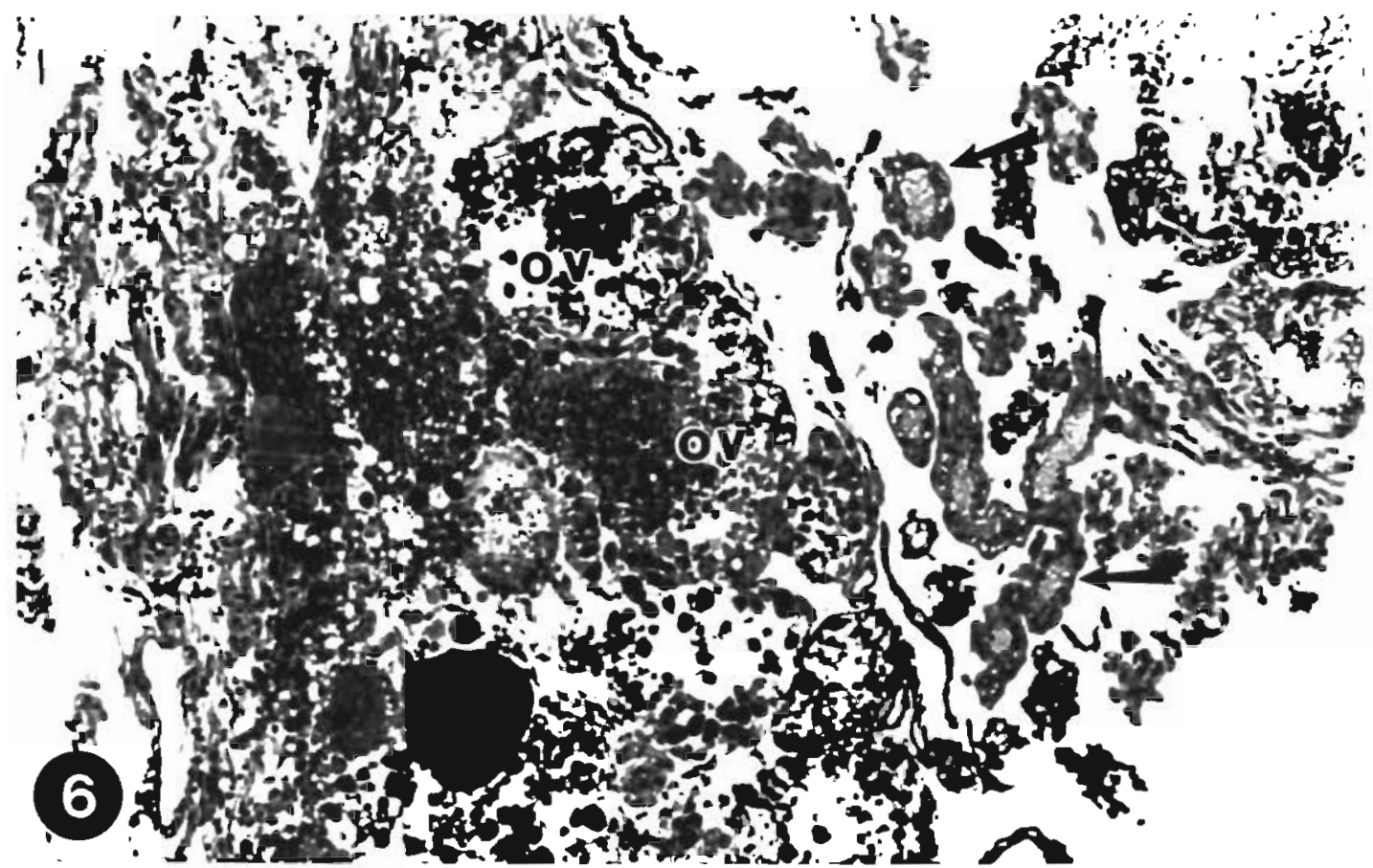

Fig. 6. Paralithodes camtschatica. Invasion by Briarosaccus callosus (arrows) of ovary. Note marked degeneration of ova (OV). Hematoxylin and eosin $100 x$ 
Matthew Island, the Pribilof Islands, and Kodiak; or of red king crabs from Bristol Bay, Kodiak, Norton Sound and, with the exception of the 2 crabs mentioned previously, Cook Inlet. The high prevalences in blue king crabs and golden king crabs in southeastern Alaska (Hawkes et al. 1985a, b) and in golden king crabs in British Columbia (Sloan 1984) may result from the silted substrates and deep fjord habitats with restricted water circulation, in contrast to the much more open, high water circulation habitats where our crabs were collected.

Acknowledgements. Many of the 1176 king crabs necropsies were performed aboard ship by R. Otto, F. Hartsock, P. Cominsky, and R. MacIntosh of the NMFS Kodiak Laboratofy; F. Blau, D. Hicks, L. Hornig, and D. Jackson of the ADF \& G; and $\mathrm{T}$. Armetta and V. Bryant of our laboratory. Most tissues

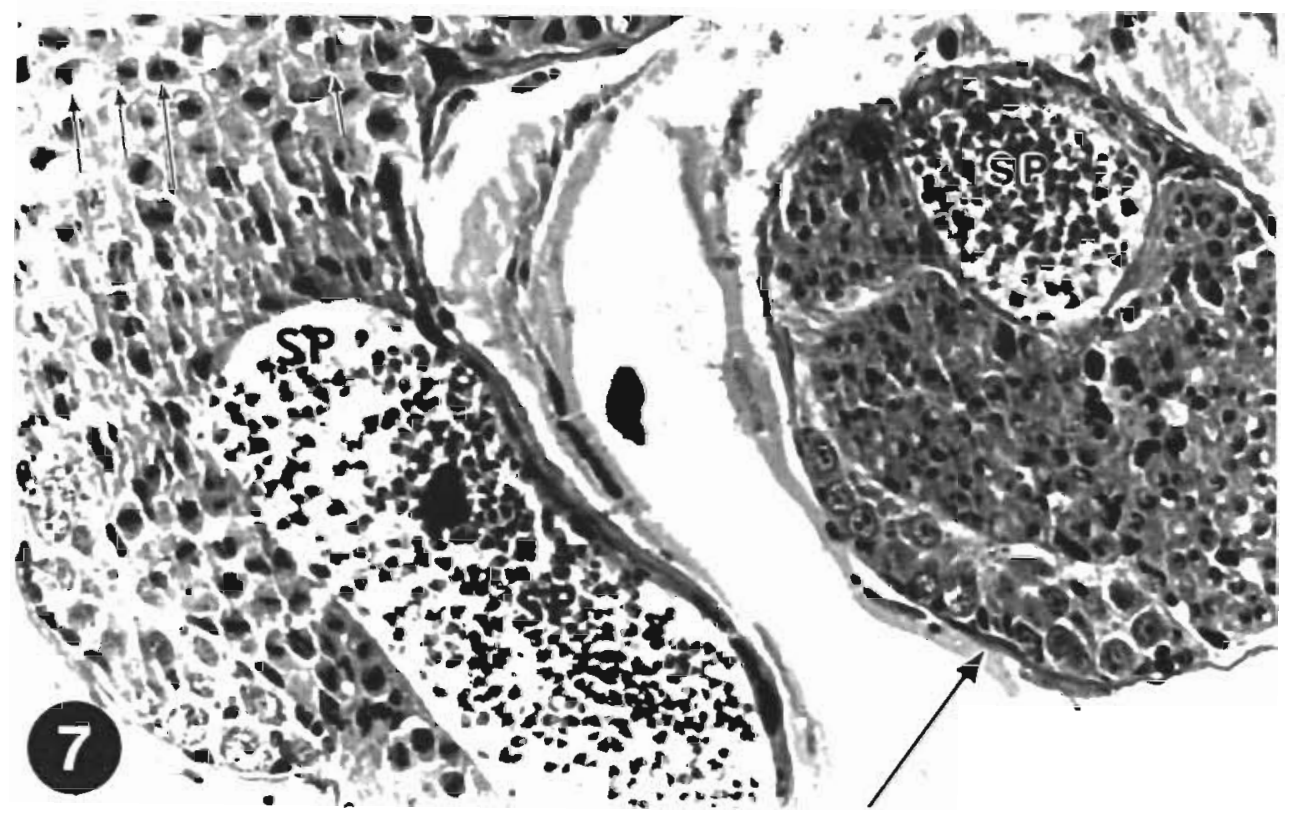

Fig. 7. Lithodes aequispina. Functional testes in crabs parasitized by Briarosaccus callosus. Note thin capsule (long arrow), numerous mitotic figures (short arrows) and numerous sperm (SP). Hematoxylin and eosin $250 x$

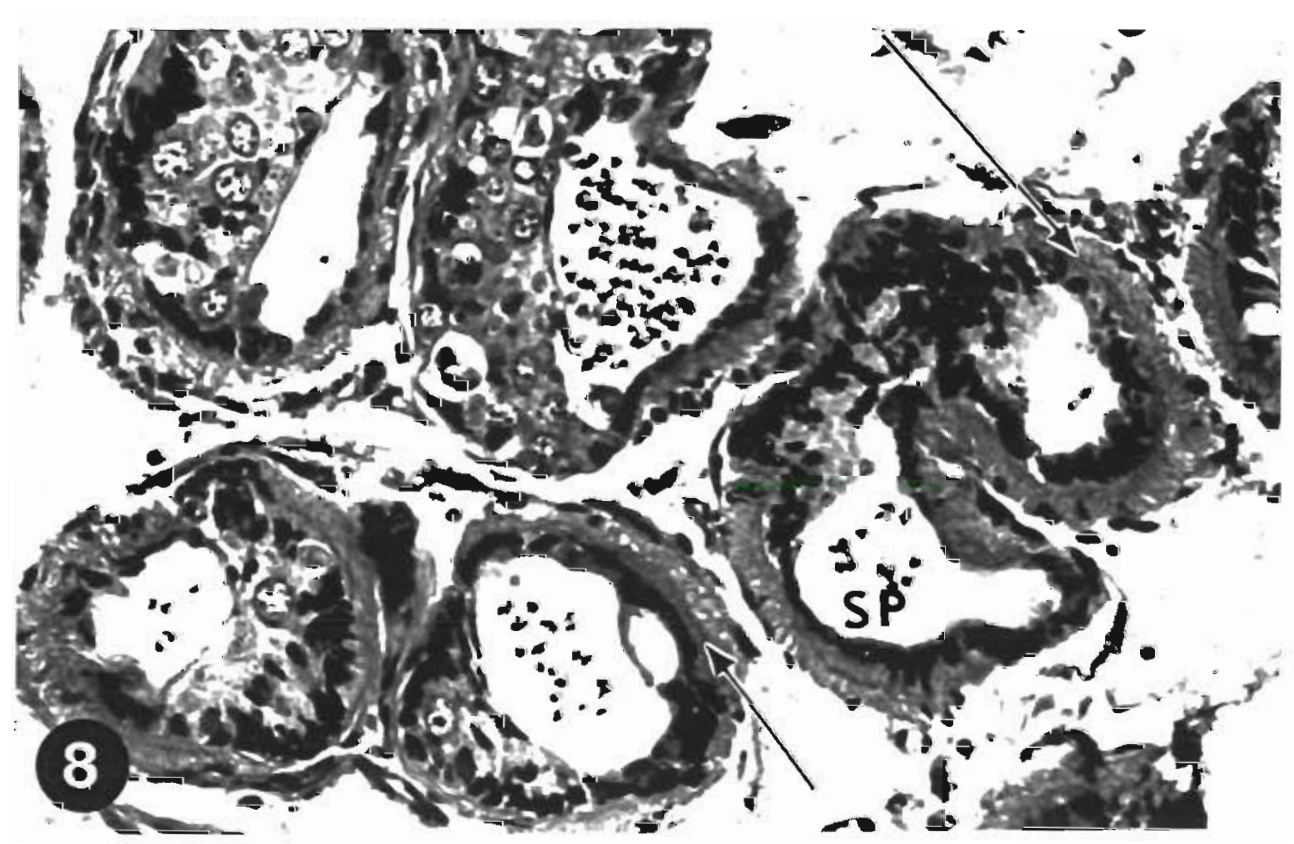

Fig. 8. Lithodes aequispina. Atrophied testes in crabs parasitized by Briarosaccus callosus. Note thickened capsule (arrows), shrunken lobules, degenerating spermatocytes, and decreased numbers of sperm (SP). Hematoxylin and eosin $250 \times$ 


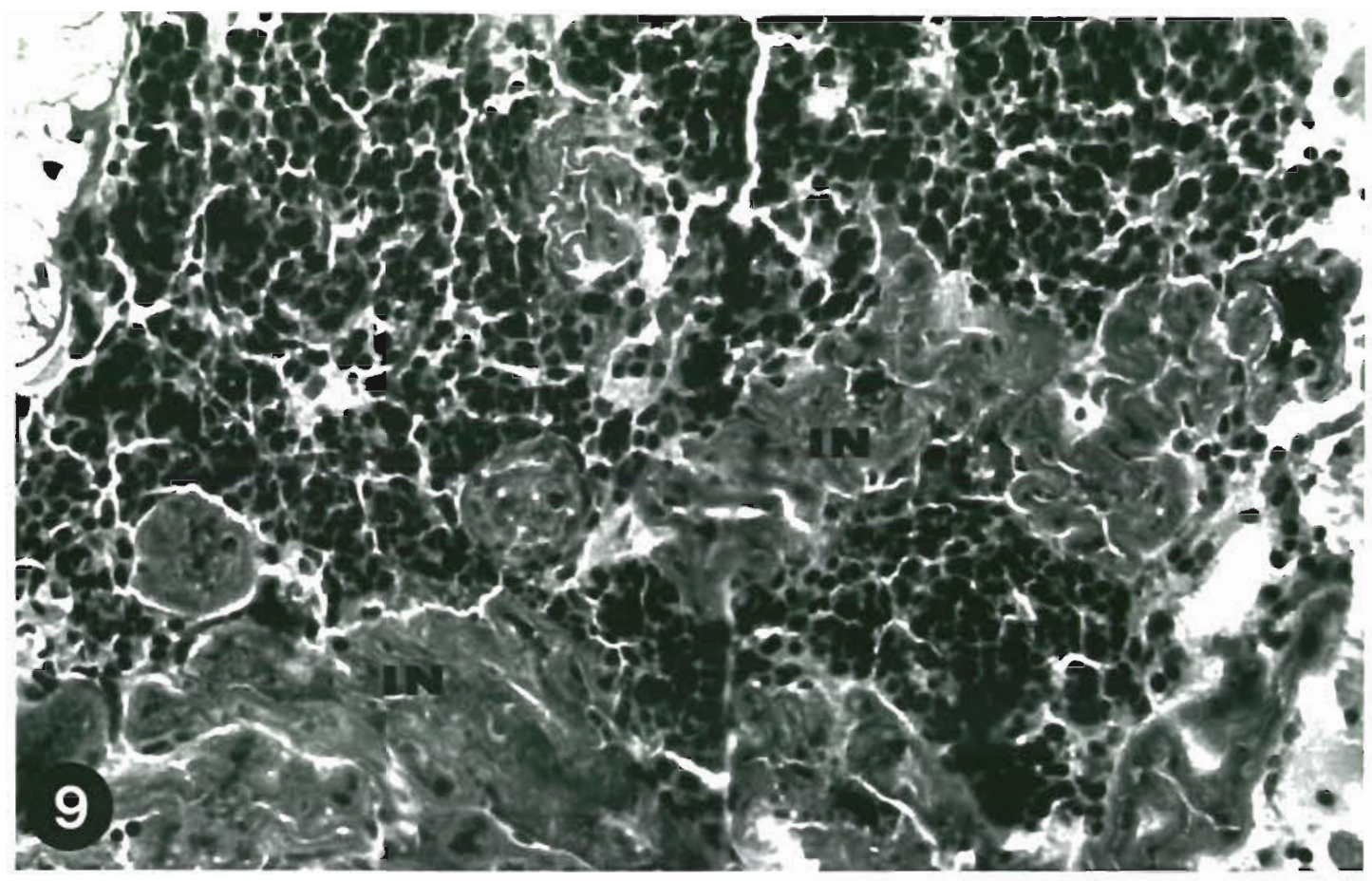

Fig. 9. Lithodes aequispina. Degenerating branches of Briarosaccus callosus interna (IN). Note massive hemocytic infiltrate. Hematoxylin and eosin $250 x$

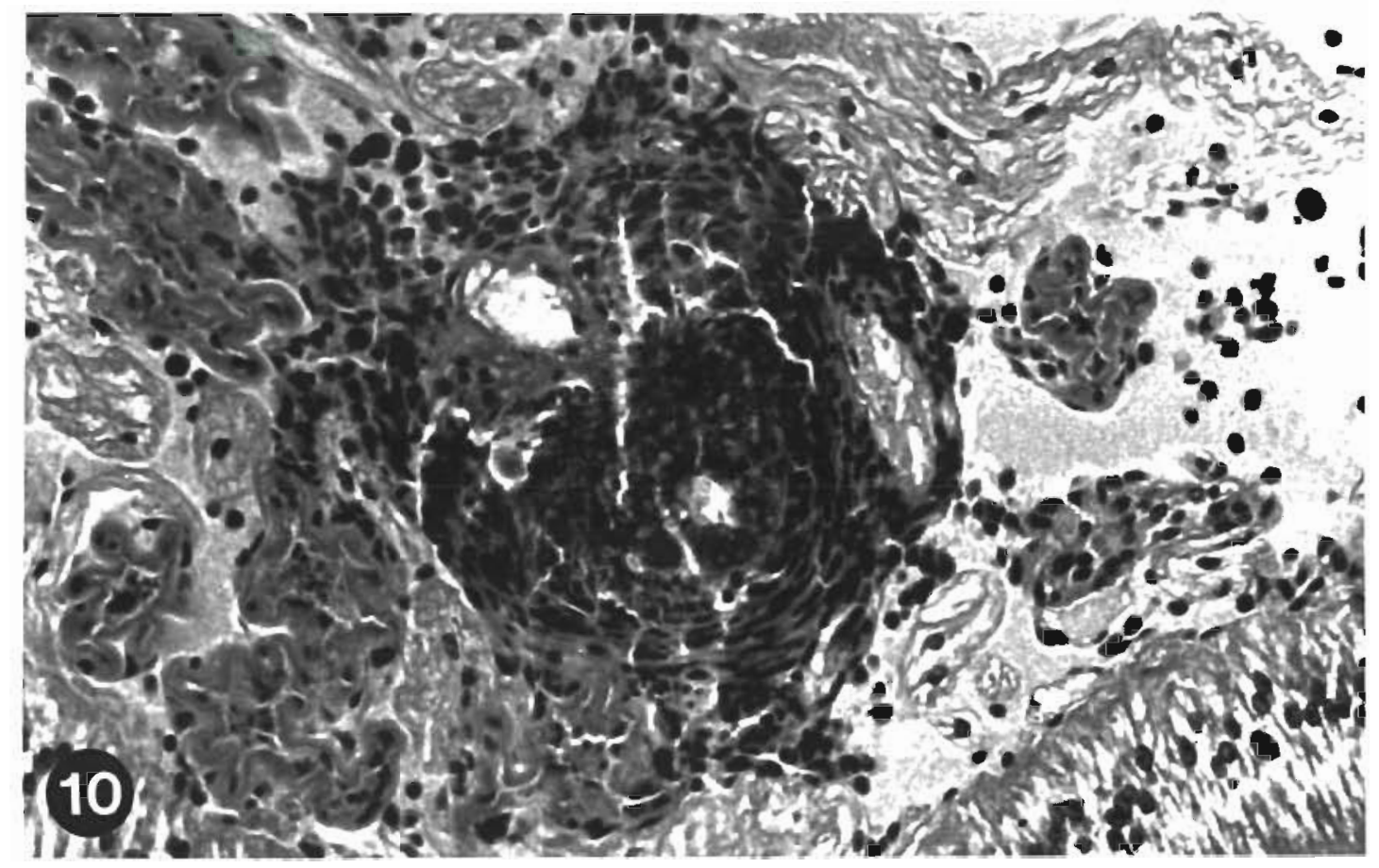

Fig. 10. Lithodes aequispina. Granulomatous infiltration and hemocytic encapsulation of degenerating Briarosaccus callosus interna. Hematoxylin and eosin $250 x$ 
were processed by $\mathrm{V}$ Bryant and T. Armetta. We also thank Drs. Susan Bower, Theodore Meyers, and Norman Sloan for their suggestions for improving the manuscript.

\section{LITERATURE CITED}

Boschma, H. (1962). Rhizocephala. 'Discovery' Rep. 33: 55-92 Boschma, H., Haynes, E. (1969). Occurrence of the rhizocephalan Briarosaccus callosus Boschma in the king crab Paralithodes camtschatica (Telesisus) in the northeast Pacific Ocean. Crustaceana 16: 97-98

Bower, S. M., Sloan, N. A. (1985). Morphology of the externa of Briarosaccus callosus Boschma (Rhizocephala) and the relationship with its host Lithodes aequispina Benedict. J. Parasitol. 71: 455-463

Hawkes, C. R., Meyers, T. R., Shirley, T. C. (1985a). Parasitism of the blue king crab Paralithodes platypus, by the rhizocephalan, Briarosaccus callosus. J. Invertebr. Pathol. 45: $252-253$

Hawkes, C. R., Meyers, T. R., Shirley, T. C. (1985b). The prevalence of the rhizocephalan, Briarosaccus callosus Boschma, a parasite in blue king crabs, Paralithodes platypus (Brandt) of southeastern Alaska. Proc. Int. King Crab Symp., Univ. Alaska. Alaska Sea Grant Rep. No. 85-12, p. 353-363

Hawkes, C. R., Meyers, T. R., Shirley, T. C., Koeneman, T. M. (1986). Prevalence of the parasitic barnacle Briarosaccus callosus on king crabs of southeastern Alaska. Trans. Am. Fish. Soc. 115: 252-257

Payen, G. G., Hubert, M., Turquier, Y., Rubiliani, C., Chasard-Bouchaud, C. (1981). Infestations expérimentales de crabes juveniles par la sacculine. Ultrastructure des racines parasitaires en croissance et relations avec la masse ganglionaire ventral de l'hôte. Can. J. Zool. 59: $1818-1826$

Rubiliani, C., Godette, G. O. (1981). Radiochemical and electrophoretic studies on the CNS of crabs parasitized with rhizocephalans; comparison with healthy crabs. Comp. Biochem. Physiol. 70B: 415-419

Rubiliani-Durozoi, M., Rubiliani, C., Payen, G. G. (1980). Déroulement des gametogeneses chez les crabes Carcinus maenas (L.) et C. mediterraneus Czerniavsky parasités par la sacculine. Int. J. Invertebr. Reprod. 2: 107-120

Rubiliani, C., Rubiliani-Durozoi, M., Payen, G. G. (1980). Effets de la sacculine sur les gonades, les glandes androgenes et le système nerveux central des crabes Carcinus maenas (L.) et C. mediterraneus Czerniavsky. Bull. Soc. zool. Fr. 105: 95-100

Sloan, N. A. (1984). Incidence and effects of parasitism by the rhizocephalan barnacle, Briarosaccus callosus Boschma, in the golden king crab, Lithodes aequispina Benedict, from deep fjords in northern British Columbia, Canada. J. exp. mar. Biol. Ecol. 84: 111-131

Sloan, N. A. (1985). Life history characteristics of fjord-dwelling golden king crabs Lithodes aequispina. Mar. Ecol. Prog. Ser. 22: 219-228

Sparks, A. K. (1985). Crustacean caused diseases: lithodid briarosacciasis. In: Synopsis of invertebrate pathology. Exclusive of insects. Chap. X. Elsevier Science Publishers, Amsterdam, p. 395-396

Sparks, A. K., Morado, J. F. (1985). A preliminary report on the diseases of Alaska king crabs. Proc. Int. King Crab Symp., Univ. Alaska. Alaska Sea Grant Rep. No. 85-12, p. 333-339

Responsible Subject Editor: Dr. J. E. Stewart; accepted for printing on November 28, 1986 